Artigo Original

\title{
Surface runoff estimate in urbanized area from the Rangel Stream basin at São Sebastião do Paraíso/MG
}

\author{
Estimativa do escoamento superficial em área urbanizada na bacia hidrográfica do Córrego Rangel \\ no Município de São Sebastião do Paraíso/MG
}

\section{Amanda Francieli de Almeida', Cristhiane Michiko Passos Okawall}

\section{Abstract}

Urban growth generates impacts over land usage and may alter the hydrological systems of a microbasin. The unregularized occupation impermeabilizes the soil and increase the volume and velocity of superficial runoff. Thus, inundation, flood and overflow occur in urban areas. In this context, this work's objective was to quantify the impact of soil impermeabilization over the surface runoff coefficient in the microbasin of the Liso stream at São Sebastião do Paraíso county, Minas Gerais. Google Earth satellite images were used for the identification and determination of occupied urban areas, and ArcGis 10.4 software was utilized for letter elaboration, which determined the permeable areas. It was taken as hypothesis that the surface runoff coefficient is equal to one in impermeabilized areas. In addition, green areas and unoccupied allotments were considered as permeable areas. In order to determine the impermeabilized area, the permeable area was subtracted from the total area. The surface runoff coefficient was estimated as the relation between the impermeabilized area and the total urbanized area. The results have demonstrated that the urbanized area located in the microbasin grew $44,47 \%$ in ten years. Therefore, the estimate of surface runoff coefficient utilized in this paper can be a good alternative for city halls to analyze the urban growth and aid in the circumscription of residential areas or green areas, since it is a simple method which requires data easily generated through maps.

Keywords: Soil impermeabilization; Urban hydrology; Urban area management

\section{Resumo}

O crescimento urbano gera impactos sobre o uso da terra e podem alterar os sistemas hidrológicos de uma microbacia. A ocupação sem regularização torna o solo impermeabilizado e apresentam aumento no volume e na velocidade do escoamento superficial, criando consequências diretas na ocorrência de inundações, enchentes e alagamentos nas áreas urbanas. Dentro desse contexto, o objetivo desse trabalho foi quantificar o impacto da impermeabilização do solo sobre o coeficiente de escoamento superficial na microbacia do córrego do Liso no município de São Sebastião do Paraíso, Minas Gerais. Para identificação e determinação da ocupação da área urbanizada, foram utilizadas imagens de satélite do Google Earth, e para elaboração das cartas foi utilizado o software ArcGis 10.4 que determinou as áreas permeáveis. Foi adotada a hipótese de que o coeficiente de escoamento superficial em áreas impermeáveis iguala-se à unidade e foram consideradas, como áreas permeáveis, as áreas verdes e as áreas correspondentes aos lotes desocupados. Para determinação da área impermeável, foi realizada a subtração da área permeável com relação à área total. O coeficiente de escoamento superficial foi estimado como a relação entre a área impermeável e a área total urbanizada. Os resultados mostraram que área urbanizada que se localiza dentro da microbacia cresceu $44,47 \%$ no período de 10 anos. Conclui-se que a estimativa do coeficiente de escoamento superficial utilizada nesse trabalho pode ser uma boa alternativa para prefeituras analisarem o crescimento urbano e auxiliar na definição de áreas residenciais ou áreas verdes, uma vez que o método é simples e necessita de dados que são facilmente gerados por mapas.

Palavras-chave: Impermeabilização do solo; Hidrologia urbana; Gestão de áreas urbanas 


\section{Introduction}

Water resources are currently at the center of environmental discussions in many knowledge areas. This concern becomes even greater with the increase of population, since there is a risk of having insufficient water quantity and quality for the population over time. It can be realized that water usage conflicts are increasing and the adequate management of resources is being needed. Therefore, analyzing hydrological systems assists in the attenuation of environmental impacts and water scarcity risks for the population.

In Brazil, cities are growing even larger once a share of rural population is migrating to urban areas each year. Thus, the urban stain is expanding and the created anthropic structures occupy part of natural landscapes. These intense changes in scenery in urban areas, such as landfills, topographical cuts and drainage canalization, provide an accelerated geomorphological evolution, altering the natural dynamics of the landscape. (Christofoletti, 2008). Seto et al. (2011) highlights that urbanization is the most irreversible way of impact over land usage, resulting in changes in soil coverage, hydrological systems, biogeochemical cycles, local microclimate and biodiversity.

According to Fontes and Barbassa (2003), the unplanned and accelerated urbanization causes profound modifications in soil usage that, on the other hand, causes permanent imprint in hydrological responses of urbanized areas. This presents the most evident effects of surface runoff increase and infiltration reduction, which has as a direct consequence the occurrence of inundation, flood and urban overflow.

This context is based at planning and urban management, whose essential role is to orient the soil occupation according to urbanistic parameters, aggregated to the urban zoning. According to Souza (2009), the Directive Plans (Planos Diretores) had a larger impact between the years of 1980 and 1990 in Brazil. This author asserts that the manner in which these occupational conditioning parameters are regulated and applied will show if the urban expansion and the directive plans update will be beneficial or maleficent for the city.

Based on this, this work's objective is to estimate the surface runoff coefficient in the microbasin of Liso stream from São Sebastião do Paraíso county, Minas Gerais.

\section{Methodology}

\subsection{Characterization of the studied area}

The microbasin of Rangel stream (Figure 1) has an area of $45,44 \mathrm{Km}^{2}$, located at the county of São Sebastião do Paraíso, southwest of Minas Gerais and belongs to the medium Rio Grande watershed. According to the Brazilian Institute of Geography and Statistics (IBGE) (2010), the county has a Human Development Index (IDH) of 0,722 and a demographic density of $79,74 \mathrm{habkm}^{-2}$. Moreover, the estimate for 2019 was that the population would be approximately seventy-thousand inhabitants.

The microbasin is found over geological formations that belongs to Araxá group, having lithology of muscovite, ferruginous quartzite and shale. The most urbanized area is over the Aquidauana formation with lithology of sandstones and siltstones (CODEMIG/CPRM, s/d). It also has quite arenaceous soils, classified by the State Foundation of the Environment of Minas Gerais (FEAM) as dystrophic red latosol, and most of the rural areas is, currently, for pastures and perennial agriculture. The studied area has temperatures of $20,6{ }^{\circ} \mathrm{C}$ on average and the annual rainfall index is $1690 \mathrm{~mm}$ (São Sebastião do Paraíso City Hall, 2018). Most part of its topography is waved (EPAMIG, 2018), and the urbanized area inside the microbasin represents $6,75 \mathrm{Km}^{2}$ and, in case the available area is considered for urban expansion, it can achieve $14,8 \mathrm{Km}^{2}$.

In a visitation in loco it was observed that the Rangel stream has its spring in the center of São Sebastião do Paraíso city, and for this reason a portion of it was channeled. The stream region had various places of sewage discharge that also have been channeled, and a fair amount was concentrated where an elevated construction that directs to sewage treatment station will be built. The urban expansion in this area is intense and, in the previous years, new allotments were constructed, which now are considered the new city center, where the new city council and new forum were installed.

According to the Directive Plan, created in 2002 and approved in 2003, the urban area of the microbasin is inserted in two residential zones: residential zones 1 and 2. Residential zone 1 has as characteristics the predominance of residential usage, of controlled densification; allowing small industries with maximum constructed area of $150 \mathrm{~m}^{2}$ and minimum permeabilization rate of $20 \%$. In comparison, residential zone 2 display the same characteristics, however the maximum constructed area for small industries is $120 \mathrm{~m}^{2}$ (Directive Plan of São Sebastião do Paraíso, 2003).

The microbasin was delimited by using the topographical chart of São Sebastião do Paraíso provided by IBGE (1971) on the scale of 1:50.000, with equal distances of contour lines of 20 meters. The studied area is presented at the location chart in Figure 1. It can be observed that the urbanized area is found in the basin headboard and that corresponds to a large part of the city.

\subsection{Photointerpretation of satellite images}

This stage established the relation between spatial distribution of impermeabilized areas and green areas of the urban area, present within the microbasin. Satellite images were used and obtained from Google Earth, since it has free access and offers good spatial resolution.

Image georeferencing and photointerpretation of areas of interest were conducted on ArcGis 10.4 software. The images were chosen from two periods of time with the interval of at least 10 years between them (2007 e 2018) in order to notice the urban growth representation, and also for it to be available to access. 
Figure 1 - Location Map of the studied area.

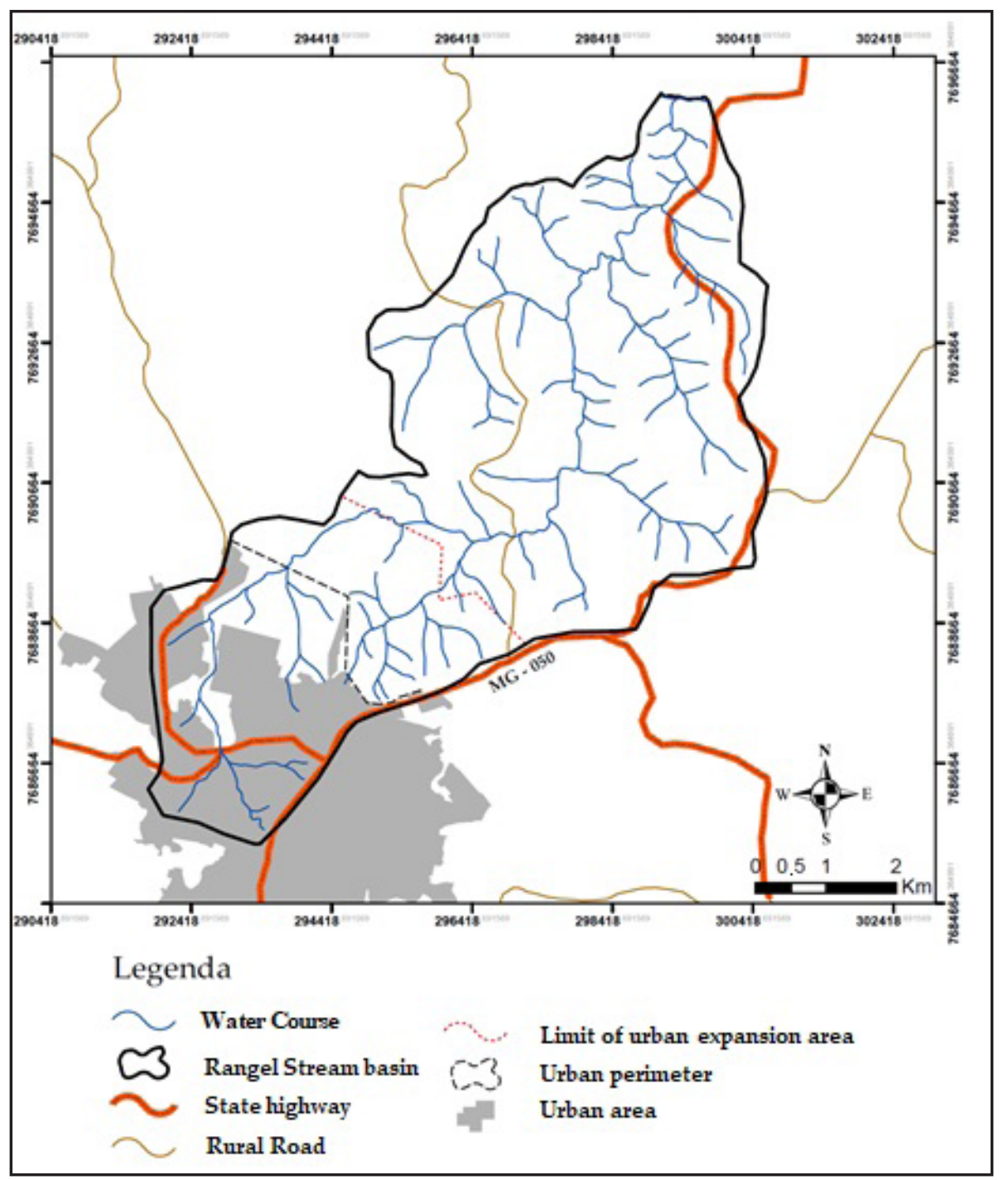

\subsection{Analysis of impermeable areas}

In order to identify the occupation of urbanized areas, the same criteria used for satellite images for the determination of soil impermeabilization stains were maintained. The permeable areas were considered as green areas defined by empty lots with no signs of construction outset, areas with abundant vegetation and allotments in initial installment fase. Therefore, for analyzing and quantifying this areas, soil occupation charts were elaborated and also tables with the values of attributes of the two periods.

\subsection{Declivity analysis}

A declivity chart was elaborated to verify the declivities of the studied area with the aid of the software ArcGis 10.4. The database for this elaboration were the scanned contour lines from the topographic chart of São Sebastião do Paraíso on the scale of 1:50.000 provided by IBGE (1971), with equal distances between contour lines of 20 meters.

\subsection{Surface Runoff Coefficient}

According to Tucci (2000a), the runoff coefficient of a basin of variable surfaces can be estimated by the weighting of the coefficient of different surfaces. Since the studied area is an urban area, in this work it was adopted the hypothesis that there are two types of surfaces (permeable and impermeable) and the following equation can be established:

$$
C=\frac{C_{P} A_{P}+C_{i} A_{i}}{A_{t}}
$$

Whereas:

$C_{P}:$ is the runoff coefficient of the permeable area; $A_{P}$ : is the basin area of permeable surface; $C_{i}$ : is the runoff coefficient of the impermeable area $A_{i}:$ is the basin area of impermeable surface;

The values of and were considered according to Table 1 , cited by Tucci (2000a), and the value of 0,84 was selected for impermeable areas and 0,13 for permeable areas. These 
Table 1 - Table of values of "C"

\begin{tabular}{lcc}
\hline \multicolumn{1}{c}{ Pavement } & Interval & Value \\
\hline Asphalt & $0,70-0,95$ & 0,83 \\
Concrete & $0,80-0,95$ & 0,88 \\
Sidewalks & $0,75-0,85$ & 0,80 \\
Roofs & $0,75-0,95$ & 0,85 \\
\hline \multicolumn{1}{c}{ Grass on arenous soil } & & \\
\hline Plane (less than 2\%) & $0,05-0,10$ & 0,08 \\
Medium declivity (2 to 7\%) & $0,10-0,15$ & 0,13 \\
High declivity (greater than 7\%) & $0,15-0,20$ & 0,18 \\
\hline
\end{tabular}

Source: Tucci (2000b).

values were defined after an observation of the characteristics of the studied area and through the declivity chart.It was not possible to define the percentage of each pavement by using the scale of elaboration of the usage and occupation map. However, the area possesses all types of pavements, then an arithmetic mean of the values were used instead.

\section{Results and Discussion}

According to the soil occupation charts (Figure 2 and Figure 3) it can be perceived that urban growth is prominent from the basin center, where new allotments were created with large lots, including one closed allotment and one area destined for the new SESC (Social Service of Commerce).
Regarding to the available permeable areas at the year of 2007, it can be observed that the most occupied lots of the city were the ones localized at both extremities, transforming the soil in an impermeable area. However, the city center still possesses several green areas, including shrub vegetation. This occurs because there are various areas and lots in the city center that are characterized as humid areas, as a possible consequence for having ground water near the surface. This areas give origin to the channels that form Ragel Stream.

It is observed that some small allotments were created quite close to the margins of the stream, and this can become a future concern for the county management, since the stream receives a great part of rainwater that flows from the city. Even the galleries and dissipators of new allotments do not seem to tolerate the water flow in intense rain seasons and need restoring.

In council legislation, the entrepreneurs of new allotments are forced to reserve a piece of 30 meters of river margins. Still, $10 \%$ of the allotment area as green or recreation areas were not included in the areas of permanent preservation (APP), in addition of being responsible for the construction of drainage for rainwater. However, at the margins of Rangel stream, perhaps this measures are not sufficient, since the soil is arenous and can have high susceptibility to erosion. Besides, some parts along the stream do not present sufficient native vegetation for protecting the stream.

The values in $\mathrm{Km}^{2}$ of the areas of interest for the study

Figure 2 - Soil Occupation Map for the 2007 period.

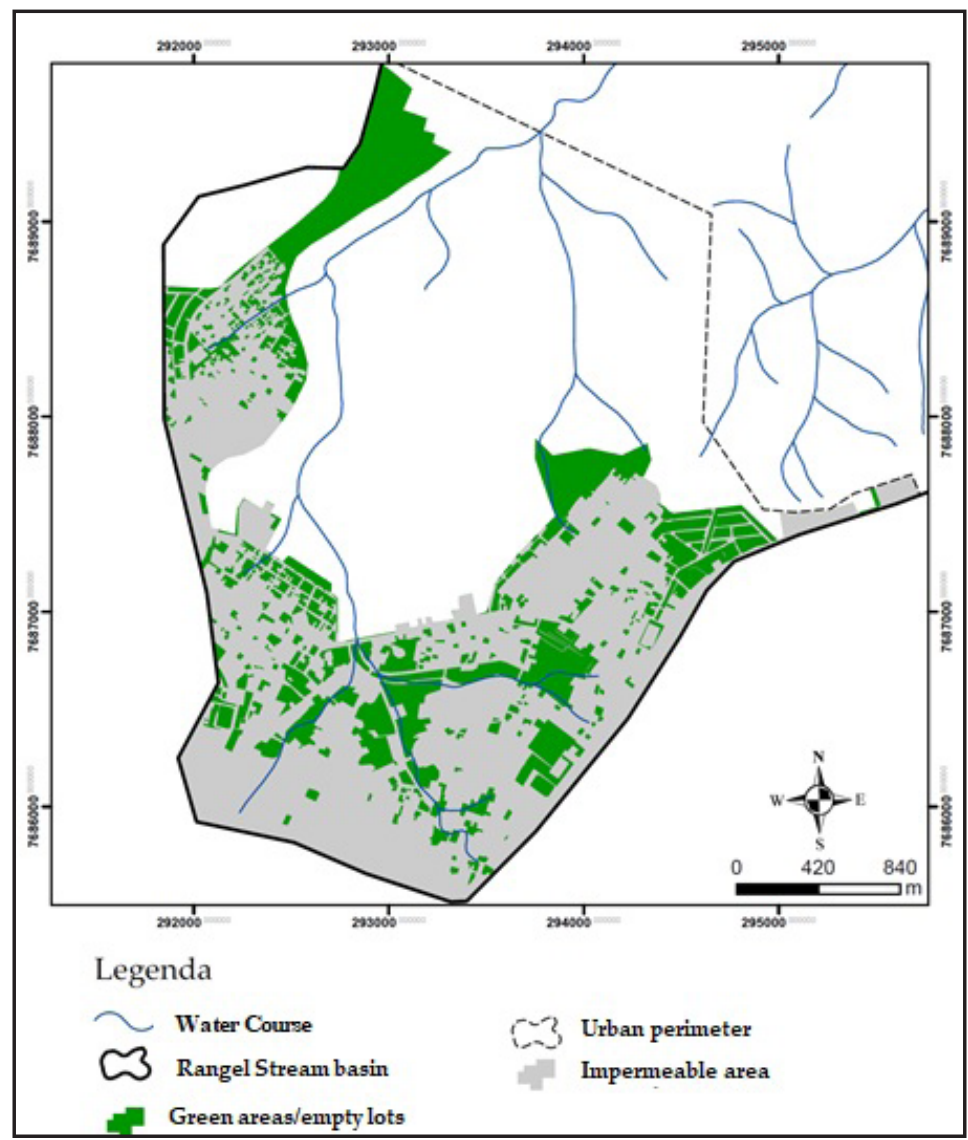


Figure 3: Soil Occupation Map for the period of 2018.

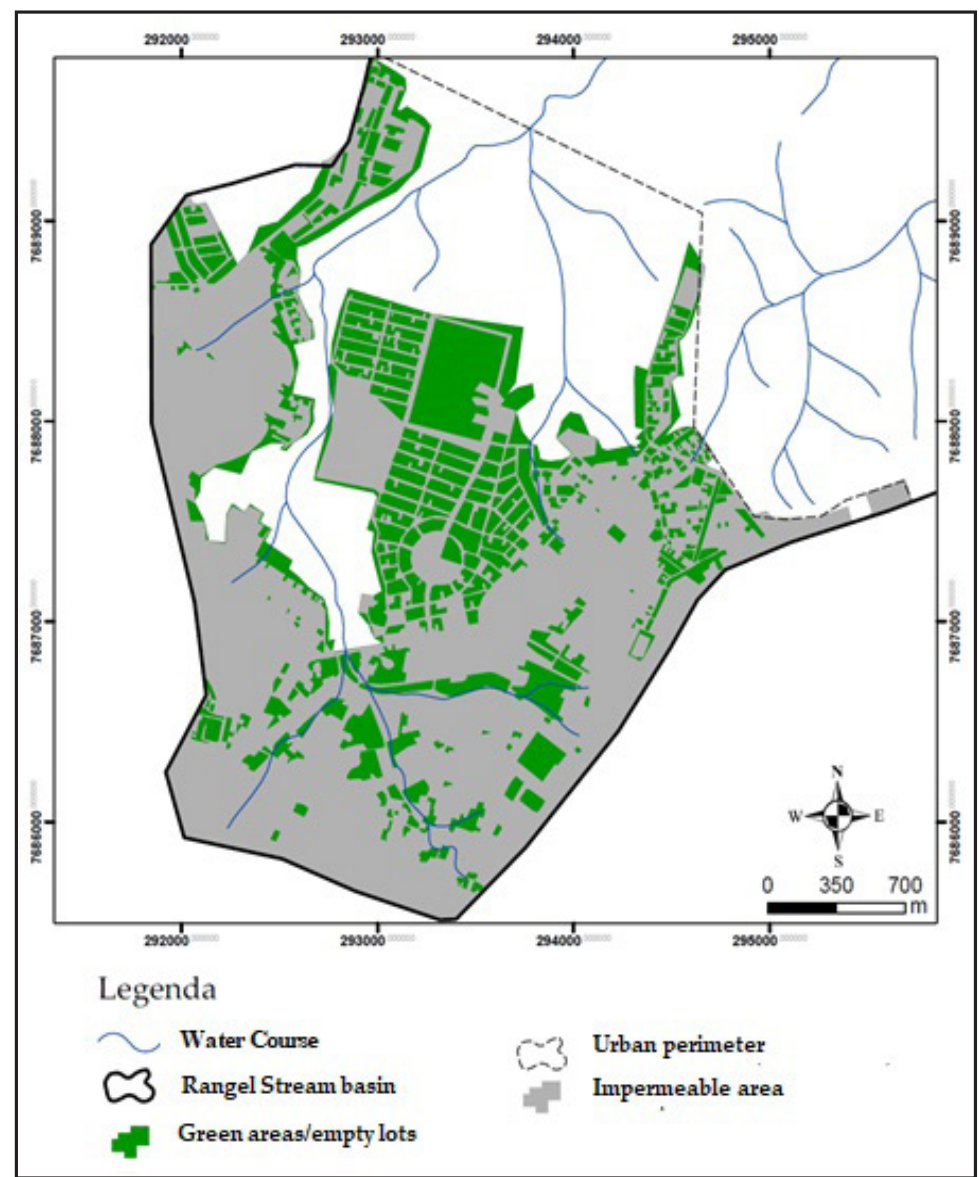

Table 2: Values of the impermeable and permeable areas at the urbanized area.

\begin{tabular}{|c|c|c|c|}
\hline \multirow{2}{*}{ Attribute } & \multicolumn{2}{|c|}{ Areas $\left(\mathrm{Km}^{2}\right)$} & \multirow[b]{2}{*}{$\%$ of growth } \\
\hline & 2007 & 2018 & \\
\hline Urbanized area & 4,67 & 6,75 & 44,47 \\
\hline Impermeable Urban area & 3,14 & 4,88 & 55,42 \\
\hline Permeable Urban area & 1,53 & 1,87 & 22,22 \\
\hline Percentage of impermeable area & $67,24 \%$ & $72,33 \%$ & - \\
\hline
\end{tabular}

were obtained from the soil occupation charts. These values can be observed on Table 2 .

The urbanized area that is located in the microbasin has grown $44,47 \%$ in a 10 year period. The tendency is that there will be an increase of impermeabilization due to the amplification of allotments, as it can be observed in the percentage of growth of the impermeabilized area that has grown more than the urban stain.

The runoff coefficient of permeable areas was defined from the declivity chart (Figure 4), which can be observed that in the urban area the predominant class is between 2 and $7 \%$. This value is considered by Tucci (2000b)'s table as medium declivity.

With the all collected data available, the runoff coefficient was calculated and the obtained values were 0,61 for the year of 2007 and 0,64 for the year of 2018 . The values did not present much difference, however, if all the empty lots, that were indicated at the 2018 chart, were occupied in the short term, the difference may become significant.

\section{Conclusions}

By observation of the soil occupation charts, it can be concluded that the city is growing towards to channel of Rangel stream. This can increase the volume and velocity of surface runoff that discharges at the stream. As a result, problems can emerge from inundation and also from margin erosions, if there are not efficient energy dissipators available. 
Figure 4 - Declivity Map of the microbasin of Rangel Stream.

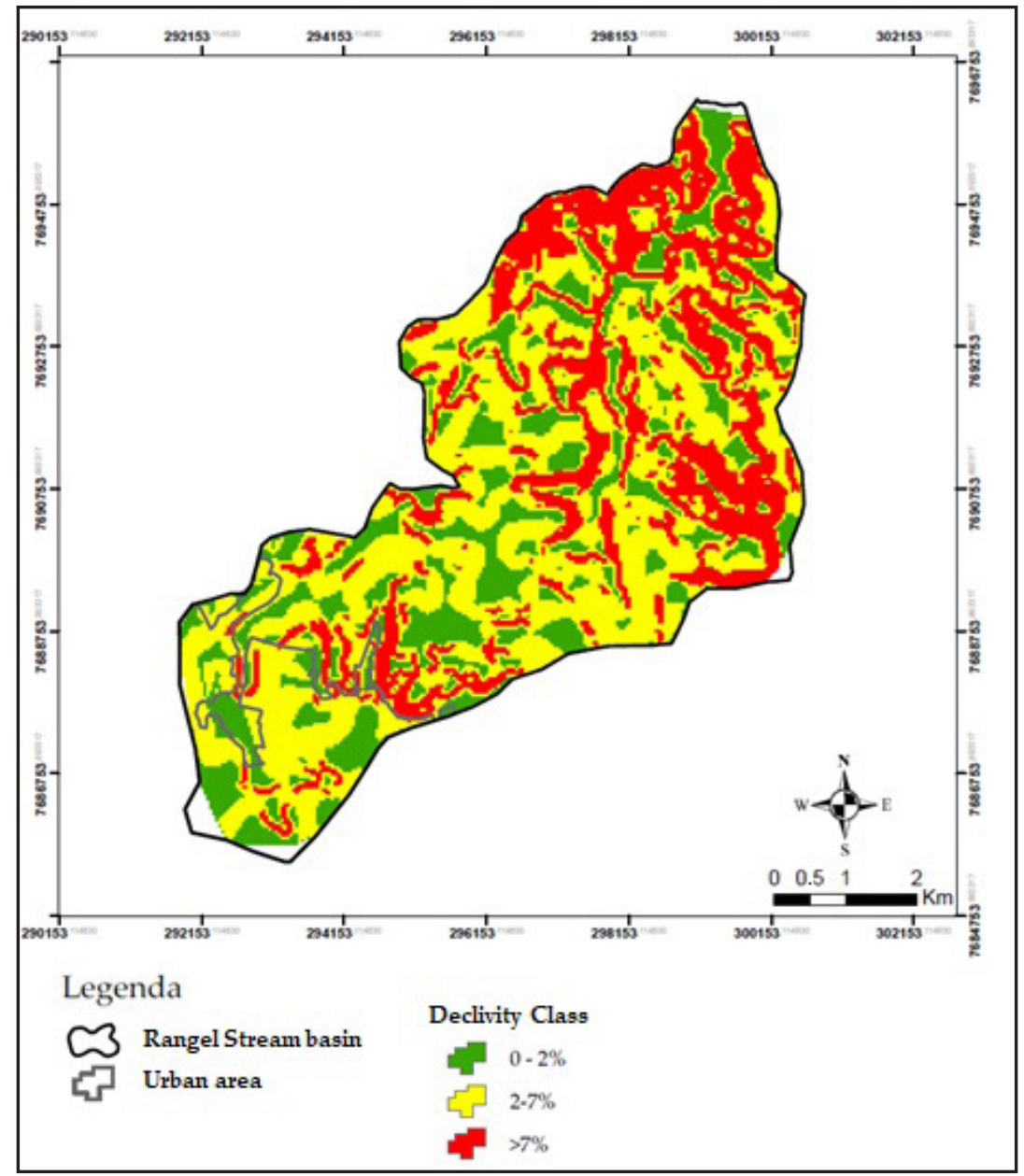

Even by having a legislation that orients the occupation areas and the rates of permeable areas that should be complied, there is a necessity of looking into this area in a more thoughtful way, revising the directive plan. Therefore, new measures of conservation should be elaborated in order to the current installed lots near the margin are not impacted by the intense precipitation. Moreover, this measures may prevent that new allotments alter the stream dynamics due to lack of vegetation in the permanent preservation areas.

The surface runoff coefficient estimative applied in this work can be a good option for city halls to analyze the urban growth and aid on the definition of residential or green areas, since the method is simple and requires data that are easily generated by maps.

\section{Acknowledgements}

Acknowledgments to CAPES for the Doctorate scholarship and to the Graduate Program in Environmental Engineering Sciences (Programa de Pós-Graduação em Ciências da Engenharia Ambiental), for providing the subject Water Resources Management, in which this paper has been written.

\section{References}

CHRistofoletti, A. (2008). Aplicabilidade do Conhecimento Geomorfológico nos Projetos de Planejamento. In: GUERRA, A. J. T.; CUNHA, S. B. (Org.). Geomorfologia - Uma Atualização de Bases e Conceitos. 8th edition. Rio de Janeiro: Bertrand Brasil.

EPAMIG. Geosolos: Mapeamento de São Sebastião do Paraíso. Available in: http://www.epamig.ufla.br/geosolos/ ssp.html. Accessed in: December 15th, 2018.

FONTES; A. R. M.; BARBASSA, A. P. (2003). Diagnóstico e Prognóstico da Ocupação e da Impermeabilização Urbana. RBRH - Revista Brasileira de Recursos Hídricos, São Paulo, v. 8, n.2, April/June 2003. p. 137 - 142.

IBGE. Censo Demográfico 2010. Rio de Janeiro: IBGE, 2010. Available in: http://censo2010.ibge.gov.br. Accessed in: July 10th, 2018.

PREFEITURA DE SÃO SEBASTIÃO DO PARAÍSO. Dados Gerais do município. Available in: http://www. paraiso.mg.gov.br/paginas.php?dsid=22. Accessed in: August 27th, 2018. 
SETO, K. C. et al. (2011). A Meta-Analysis of Global Urban Land Expansion. PLoS ONE, 6(8).

SOUZA, M.L. (2009). Mudar a cidade: uma introdução crítica ao planejamento e à gestão urbana. 2. ed. Rio de Janeiro: Bertrand Brasil.

TUCCI, C. E. M. (2000a). Coeficiente de Escoamento e Vazão Máxima de Bacias Urbanas. In: Revista Brasileira de Recursos Hídricos, Volume 5, n. 1, p.61-68.

TUCCI, C. E. M. (2000b). Estimativa do Volume para Controle da Drenagem no Lote. In: Avaliação e Controle da Drenagem Urbana. Porto Alegre: Ed. Universidade/ ABRH, p. 395-401. 